\title{
Pengaruh Profitabilitas dan Ukuran Perusahaan Terhadap Nilai Perusahaan Dengan Moderasi Kebijakan Dividen: Studi Pada Perusahaan Properti, Real Estate dan Konstruksi Bangunan Yang Terdaftar di Bursa Efek Indonesia Periode 2013-2017
}

\author{
Ali Imron \& Desi Kurniawati \\ Fakultas Ekonomi dan Bisnis Untirta \\ Email: research082018@gmail.com
}

\begin{abstract}
This study purposed to determine the effect of profitability proxy with Earning Per Share (EPS) and firm size is proxied by logarithm natural of total assets to firm value which proxied by Price Book Value (PBV) and to find out whether dividend policy proxied by Dividend Payout Ratio (DPR) be moderateted the relationship of profitability and firm size against firm value. The population in this study were all the property, real estate and building construction companies sector listed on Indonesia Stock Exchange for 2013 -2017. The sample in this study were 9 companies out of 62 population obtained through purposive sampling method. Data analysis techniques used in this study was Moderated Regression Analysis (MRA). The results of this study is: (1) Profitability has positive and significant impact to firm value. (2) Firm size has positive impact but not significant to firm value. (3) Dividend policy are able to moderate the effect of profitability against firm value. (4) Dividend policy can not moderate the effect of firm size against firm value.
\end{abstract}

Keywords: Profitability, Firm Size, Dividend Policy and Firm Value

\section{Pendahuluan}

Perkembangan bisnis yang kian pesat telah menciptakan persaingan yang semakin kompetitif antar perusahaan. Persaingan tersebut mengharuskan adanya perubahan cara pandang dari para pelaku ekonomi agar dapat semakin meningkatkan kinerja perusahaan sehingga tujuannya dapat tercapai. Seperti kita ketahui tujuan utama perusahaan yang telah go public adalah meningkatkan kemakmuran para pemegang saham melalui peningkatan nilai perusahaan. Nilai perusahaan menjadi sangat penting karena mencerminkan kinerja perusahaan yang selanjutnya dapat mempengaruhi persepsi investor terhadap suatu perusahaan.

Semakin ketatnya pertumbuhan perusahaan tentu menjadi pressure bagi setiap perusahaan agar mampu bersaing dengan perusahaan lain. Nilai perusahaan merupakan salah satu tolak ukur investor dalam melihat tingkat keberhasilan suatu perusahaan. Nilai perusahaan dapat dilihat dari harga sahamnya. Harga saham yang tinggi akan meningkatkan kepercayaan investor terhadap kinerja perusahaan tersebut dan prospek di masa mendatang. Nilai perusahaan yang tinggi akan diikuti oleh kesejahteraan pemegang saham. 
Nilai perusahaan diantaranya diukur menggunakan rasio Price Book Value (PBV). Price Book Value (PBV) yakni rasio yang mampu menggambarkan kondisi yang terjadi di pasar. Rasio ini dapat memberikan pemahaman bagi pihak manajemen perusahaan dalam menganalisa kondisi pasar yang akan berdampak pada perusahaan. Price Book Value (PBV) yang tinggi mencerminkan tingkat kemakmuran pemegang saham, dimana kemakmuran pemegang saham merupakan tujuan utama dari sebuah perusahaan.

Kinerja keuangan sebuah perusahaan menjadi salah satu faktor yang menjadi perhatian para investor ketika akan membeli saham di sebuah perusahaan. Laporan keuangan yang diterbitkan oleh sebuah perusahaan dapat menjadi cerminan dari kinerja keuangan perusahaan dimana data yang terdapat dalam laporan keuangan tersebut dapat berfungsi sebagai informasi, alat pertanggungjawaban manajemen kepada pemilik perusahaan, dan juga sebagai gambaran terhadap indikator keberhasilan perusahaan serta sebagai bahan pertimbangan dalam pengambilan keputusan.

\section{Tinjauan Literatur}

Salah satu faktor yang mempengaruhi nilai perusahaan adalah profitabilitas (Armereo, 2015; Halin, 2016; Purnamasari, 2017; Sayadi, 2019). Menurut Kasmir (2014) rasio profitabilitas merupakan rasio untuk menilai kemampuan perusahaan dalam mencari keuntungan. Profitabilitas dianggap mampu mempengaruhi nilai perusahaan. Semakin baik pertumbuhan profitabilitas perusahaan berarti prospek perusahaan di masa depan dinilai semakin baik, artinya nilai perusahaan juga akan dinilai semakin baik di mata investor. Semakin besar laba yang diterima oleh pemegang saham akan menjadi sinyal positif bagi investor dalam menilai sebuah perusahaan, yaitu perusahaan tersebut dianggap sebagai perusahaan yang profitable dan mempunyai prospek yang baik dimasa depan. Secara empiric, penelitian dilakukan Suwardika beserta Mustanda (2017) menyatakan profitabilitas berpengaruh positif signifikan terhadap nilai perusahaan. Sejalan dengan dengan penelitian Novari dan Lestari (2016) yang menunjukkan hasil yang sama yaitu profitabilitas memiliki pengaruh positif signifikan terhadap nilai perusahaan. Berbeda dengan hasil penelitian Kusumayanti dan Astika (2016) yang hasilnya menunjukkan bahwa profitabilitas tidak memiliki pengaruh terhadap nilai perusahaan.

Faktor lain yang berpengaruh terhadap nilai perusahaan adalah ukuran perusahaan (size). Ukuran peusahaan (size) merupakan suatu indikator yang menunjukkan kekuatan finansial perusahaan dimana dalam mengukur ukuran perusahaan dapat menggunakan logaritma natural dari total aset. Ukuran perusahaan dianggap mampu mempengaruhi nilai perusahaan karena semakin besar ukuran atau skala perusahaan maka akan semakin mudah pula perusahaan memperoleh sumber pendanaan baik yang bersifat internal maupun eksternal. Ukuran perusahaaan pada umumnya dapat berpengaruh pada penilaian investor dalam membuat keputusan investasi. Berdasarkan Undang-Undang Nomor 20 Tahun 2008 kriteria ukuran perusahaan yang termasuk ke dalam usaha besar adalah perusahaan yang memiliki total aset lebih dari 10 milyar (tidak termasuk tanah dan bangunan).

Secara empirik, penelitian mengenai pengaruh ukuran perusahaan terhadap nilai perusahaan telah dilakukan Novari dan Lestari (2016) dimana hasilnya menunjukkan ukuran perusahaan memiliki pengaruh positif signifikan terhadap nilai perusahaan. Hasil

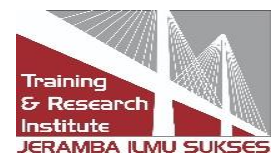


ini juga sejalan dengan penelitian yang dilakukan oleh Putra dan Lestari (2016) bahwa ukuran perusahaan berpengaruh positif signifikan terhadap nilai perusahaan. Namun hal ini berbeda dengan penelitian yang dilakukan oleh Suwardika dan Mustanda (2017) dimana hasilnya menunjukkan bahwa ukuran perusahaan tidak berpengaruh terhadap nilai perusahaan.

Berdasarkan hasil penelitian sebelumnya yang masih terdapat ketidakkonsistenan pengaruh profitabilitas terhadap nilai perusahaan serta pengaruh ukuran perusahaan terhadap nilai perusahaan, maka kemungkinan ada variabel lain yang mempengaruhinya. Penelitian ini menambahkan kebijakan dividen sebagai variabel moderasi untuk mengetahui apakah benar kebijakan dividen dapat mempengaruhi profitabilitas dan ukuran perusahaan dalam meningkatkan nilai perusahaan.

Kebijakan dividen pada dasarnya adalah penentuan besarnya porsi keuntungan yang akan diberikan kepada pemegang saham. Kebijakan pembayaran dividen merupakan hal penting yang menyangkut apakah arus kas masuk (cash in flow) akan dibayarkan kepada investor sebagai dividen atau akan ditahan untuk diinvestasikan kembali oleh perusahaan. Dividen merupakan hak pemegang saham terhadap laba yang dihasilkan oleh perusahaan atas kegiatan bisnisnya. Besarnya dividen dapat mempengaruhi harga saham, karena dividen merupakan sinyal bagi para investor untuk menilai apakah suatu perusahaan dapat dikatakan profitable atau tidak. Apabila dividen yang dibayarkan tinggi, maka peminat saham suatu perusahaan akan semakin banyak. Sesuai dengan teori permintaan, jika permintaan akan saham meningkat, maka harga saham akan cenderung tinggi sehingga hal tersebut dapat meningkatkan nilai perusahaan.

\section{Metode Penelitian}

Penelitian ini menggunakan jenis penelitian kausalitas yang bertujuan untuk mengetahui hubungan atau pengaruh antara dua variabel atau lebih. Pendekatan yang digunakan dalam penelitian ini adalah pendekatan kuantitatif untuk mengetahui hubungan variabel dalam penelitian.

Terdapat tiga jenis variabel dalam penelitian ini, yaitu variabel independen, variabel dependen, dan variabel moderasi. Variabel independen dalam penelitian ini yaitu profitabilitas yang diproksikan dengan Earning Per Share (EPS) dan ukuran perusahaan yang diproksikan dengan logaritma natural dari total aset (Ln of total assets). Sedangkan variabel dependen dalam penelitian ini adalah nilai perusahaan yang diproksikan dengan Price Book Value (PBV) dan variabel moderasi dalam penelitian ini adalah kebijakan dividen yang diproksikan dengan Dividend Payout Ratio (DPR).

Penelitian ini mengambil objek perusahaan properti, real estate dan konstruksi bangunan. Populasi dalam penelitian ini sebanyak 62 perusahaan sesuai publikasi Indonesian Capital Market Directory (ICMD) tahun 2013-2017. Sampel dalam penelitian ini berjumlah 9 perusahaan yang terdaftar di Bursa Efek Indonesia periode 2013-2017. Teknik yang digunakan dalam pengambilan sampel adalah dengan menggunakan teknik purposive sampling. Berikut adalah kriteria dalam pengambilan sampel:

Tabel 1. Tabel Kriteria Pengambilan Sampel 


\begin{tabular}{|c|l|c|}
\hline \hline No. & \multicolumn{1}{|c|}{ Keterangan } & Jumlah \\
\hline 1. & $\begin{array}{l}\text { Perusahaan sektor properti, real estate dan konstruksi bangunan } \\
\text { yang terdaftar di BEI selama 2013-2017 yang menjadi populasi } \\
\text { dalam penelitian ini; }\end{array}$ & 62 \\
\hline 2. & $\begin{array}{l}\text { Perusahaan sektor properti, real estate dan konstruksi bangunan } \\
\text { yang tidak konsisten terdaftar di BEI selama tahun 2013 - 2017; }\end{array}$ & $(15)$ \\
\hline 3. & $\begin{array}{l}\text { Perusahaan sektor real estate, properti dan konstruksi bangunan } \\
\text { tidak konsisten mempublikasikan laporan keuangan serta } \\
\text { membayarkan dividen selama tahun 2013-2017. }\end{array}$ & $(38)$ \\
\hline & $\begin{array}{l}\text { Jumlah sampel keseluruhan perusahaan sektor properti, real estate } \\
\text { dan konstruksi bangunan yang memenuhi kriteria sampel }\end{array}$ & 9 \\
\hline
\end{tabular}

Diperoleh 9 perusahaan yang memenuhi kriteria untuk dijadikan sampel dalam penelitian:

Tabel 2. Sampel Penelitian

\begin{tabular}{|c|c|l|c|}
\hline NO & KODE & \multicolumn{1}{|c|}{ NAMA EMITEN } & TANGGAL - IPO \\
\hline \multicolumn{3}{|c|}{ SEKTOR PROPERTI DAN REAL ESTATE } \\
\hline 1 & CTRA & Ciputra Development Tbk. & 28 Maret 1994 \\
\hline 2 & GMTD & $\begin{array}{l}\text { Gowa Makassar Tourism Development } \\
\text { Tbk. }\end{array}$ & 11 Desember 2000 \\
\hline 3 & MKPI & Metropolitan Kentjana Tbk. & 10 Juli 2009 \\
\hline 4 & MTLA & Metropolitan Land Tbk. & 20 Juni 2011 \\
\hline 5 & PWON & Pakuwon Jati Tbk. & 24 Juni 2013 1989 \\
\hline \multicolumn{5}{|c|}{ SUB SEKTOR KONSTRUKSI BANGUNAN } \\
\hline 6 & ACST & Acset Indonusa Tbk. & 25 Juli 2006 Oktober 2007 \\
\hline 7 & TOTL & Total Bangun Persada Tbk. & 19 Desember 2012 \\
\hline 8 & WIKA & Wijaya Karya (Persero) Tbk. & Waskita Karya (Persero) Tbk.
\end{tabular}

Jenis data yang digunakan dalam penelitian ini yaitu data kuantitatif. Sedangkan sumber data yang digunakan dalam penelitian ini yaitu data sekunder. Data sekunder dalam penelitian ini diperoleh dari Indonesian Capital Market Directory (ICMD) serta dari Galeri Bursa Efek Indonesia (BEI) di laman www.idx.co.id yang berupa data laporan keuangan dan dari situs www.sahamok.com. Data yang diperoleh berupa laporan keuangan perusahaan sektor properti, real estate dan konstruksi bangunan yang terdaftar di BEI selama tahun 2013-2017.

Metode pengumpulan data yang digunakan dalam penelitian ini adalah Library Research dan Documentative Research. Metode Library Research dapat diperoleh dari buku, skripsi dan jurnal terdahulu. Sedangkan metode Documentative research dilakukan dengan cara mencari, mengumpulkan, mencatat, dan mengkaji data yang berhubungan dengan perusahaan, data tersebut dapat diperoleh di Galeri BEI dalam laman www.idx.co.id maupun Indonesian Capital Market Directory pada sektor properti, real estate dan konstruksi bangunan periode 2013-2017. Sedangkan teknik analisis data yang digunakan dalam penelitian ini yaitu analisis regresi multivariate dengan bantuan software SPSS 21. 


\section{Hasil dan Pembahasan}

Tabel 3. Hasil Analisis Statistik Deskriptif

\begin{tabular}{|l|c|c|c|c|c|}
\hline & $\mathrm{N}$ & Minimum & Maksimum & Mean & $\begin{array}{c}\text { Std. } \\
\text { Deviation }\end{array}$ \\
\hline PBV & 45 & 0,74 & 7,60 & 2,5220 & 1,65302 \\
\hline EPS & 45 & 23,60 & $1.264,90$ & 265,6258 & 380,34517 \\
\hline SIZE & 45 & 27,84 & 32,21 & 29,5758 & 1,21686 \\
\hline DPR & 45 & 2,38 & $1.042,43$ & 62,5742 & 179,63158 \\
\hline
\end{tabular}

Hasil uji statistik deskriptif Nilai minimum dari $P B V$ sebesar 0,74 dimiliki perusahaan Metropolitan Land Tbk. (MTLA) dengan nilai maksimum 7,60 dimiliki perusahaan Metropolitan Kentjana Tbk. (MKPI). Nilai minimum Earning Per Share (EPS) sebesar 23,60 dimiliki oleh perusahaan Pakuwon Jati Tbk. (PWON) dan nilai maksimum sebesar 1.264,90 yang dimiliki oleh perusahaan Metropolitan Kentjana Tbk. (MKPI). Nilai minimum Size sebesar 27,84 dimiliki oleh perusahaan Gowa Makassar Tourism Development Tbk. (GMTD) dan nilai maksimum dimiliki oleh perusahaan Waskita Karya Tbk. (WSKT) sebesar 32,21. Nilai minimum Dividend Payout Ratio dimiliki oleh perusahaan Gowa Makassar Tourism Development Tbk. (GMTD) sebesar 2,38 dan nilai maksimum sebesar 1.042,43 dimiliki oleh perusahaan Metropolitan Land Tbk. (MTLA).

Uji normalitas bertujuan untuk menguji apakah dalam model regresi, variabel pengganggu atau residual memiliki distribusi normal.

Tabel 4. Hasil Pengujian Normalitas (Kolmogorov - Smirnov)

\begin{tabular}{|c|c|}
\hline \multicolumn{2}{|l|}{ One-Sample Kolmogorov-Smirnov Test } \\
\hline & $\begin{array}{c}\text { Unstandardized } \\
\text { Residual }\end{array}$ \\
\hline $\mathrm{N}$ & 45 \\
\hline Normol Dorometora a,b & .0000000 \\
\hline Std. Deviation & 1.66771887 \\
\hline \begin{tabular}{l|l} 
Fxtreme Absolute \\
\end{tabular} & .102 \\
\hline Extreme $\overline{\text { Positive }}$ & .102 \\
\hline Negative & -.058 \\
\hline Kolmogorov-Smirnov Z & .685 \\
\hline Asymp. Sig. (2-tailed) & .736 \\
\hline Sig. & $.704^{\mathrm{c}}$ \\
\hline ConfidenceLower Bound & .692 \\
\hline Upper Bound & .716 \\
\hline \multicolumn{2}{|l|}{ a. Test distribution is Normal. } \\
\hline \multicolumn{2}{|l|}{ b. Calculated from data. } \\
\hline
\end{tabular}

Sumber: Output SPSS 21.0 data diolah

Hasil uji normalitas (Kolmogorov-Smirnov) terlihat nilai Asymp. Sig sebesar 0,736 lebih dari $0,05(0,736>0,05)$. Hal ini menunjukkan bahwa data berdistribusi normal sehingga model regresi tersebut layak untuk memprediksi variabel dependen PBV dengan menggunakan variabel independen profitabilitas-EPS dan (Size Firm). 
Uji multikolinieritas bertujuan untuk menguji apakah model regresi ditemukan adanya korelasi antar variabel bebas (independen). Model regresi yang baik adalah apabila tidak terjadi korelasi di antara variabel independen.

Tabel 5. Hasil Pengujian Multikolinieritas (Nilai VIF)

\begin{tabular}{|c|c|c|c|c|c|c|c|c|}
\hline \multicolumn{9}{|c|}{ Coefficients $^{\mathrm{a}}$} \\
\hline \multirow{2}{*}{\multicolumn{2}{|c|}{ Model }} & \multicolumn{2}{|c|}{$\begin{array}{c}\text { Unstandardized } \\
\text { Coefficients }\end{array}$} & \multirow{2}{*}{\begin{tabular}{|c|}
$\begin{array}{c}\text { Standardized } \\
\text { Coefficients }\end{array}$ \\
Beta \\
\end{tabular}} & \multirow[t]{2}{*}{$\mathrm{T}$} & \multirow[t]{2}{*}{ Sig. } & \multicolumn{2}{|c|}{$\begin{array}{l}\text { Collinearity } \\
\text { Statistics }\end{array}$} \\
\hline & & $\mathrm{B}$ & Std. Error & & & & Tolerance & VIF \\
\hline \multirow{3}{*}{1} & (Constant) & -5.043 & 6.782 & & -.744 & .461 & & \\
\hline & Earning Per Share (X1) & .002 & .001 & .400 & 2.607 & .013 & .870 & 1.149 \\
\hline & Ukuran Perusahaan (X2) & .246 & .227 & .166 & 1.084 & .285 & .870 & 1.149 \\
\hline
\end{tabular}

Sumber: data diolah Output SPSS 21.0

Hasil uji multikolinieritas dengan melihat nilai VIF, maka dapat dilihat nilai VIF untuk variabel Earning Per Share (EPS) yaitu sebesar 1,149 dan nilai VIF untuk variabel ukuran perusahaan (size) sebesar 1,149 dimana keduanya menunjukkan hasil kurang dari 10 (nilai VIF EPS $\leq 10$ dan nilai VIF Size $\leq 10$ ). Berdasarkan hasil tersebut maka dapat diinterpretasikan bahwa tidak terjadi multikolinieritas antar variabel independen dalam model regresi sehingga data paddiatasa penelitian ini telah memenuhi syarat uji asumsi klasik dalam hal ini adalah uji multikolinieritas.

Uji heteroskedastisitas bertujuan menguji apakah dalam model regresi terjadi ketidaksamaan variance dari residual satu pengamatan ke pengamatan yang lain. Model regresi yang baik adalah yang homoskedastisitas yaitu jika variance dari residual satu pengamatan ke pengamatan lain tetap.

Tabel 6. Hasil Pengujian Heteroskedastisitas (Uji White)

\begin{tabular}{|c|r|r|r|r|}
\hline \multicolumn{5}{|c|}{ Model Summary } \\
\hline Model & R & R Square & $\begin{array}{c}\text { Adjusted R } \\
\text { Square }\end{array}$ & $\begin{array}{c}\text { Std. Error of } \\
\text { the Estimate }\end{array}$ \\
\hline 1 & $.591^{\mathrm{a}}$ & .349 & .266 & 3.21675 \\
\hline
\end{tabular}

a. Predictors: (Constant), EPS_SIZE, SIZE2, EPS2, Earning Per Share (X1), Ukuran Perusahaan (X2)

Sumber: Output SPSS 21.0 data diolah

Diperoleh nilai $\mathrm{R}^{2}$ sebesar 0,349 dengan jumlah data observasi sebanyak 45 data. Maka, besarnya nilai $\mathrm{C}^{2}$ hitung:

$$
\begin{array}{ll}
\mathrm{C}^{2} \text { hitung } & =\mathrm{n} \times \mathrm{R}^{2} \\
\mathrm{C}^{2} \text { hitung } & =45 \times 0,349 \\
\mathrm{C}^{2} \text { hitung } & =15,705 \\
\mathrm{C}^{2} \text { tabel df } & =45-2=43 \text { adalah 59,30351 }
\end{array}
$$


Uji white diperoleh nilai $C^{2}$ hitung sebesar 15,705 dan nilai $C^{2}$ tabel sebesar 59,30351. Dengan demikian nilai $C^{2}$ hitung $<$ nilai $C^{2}$ tabel $(15,705<59,30351)$ maka dapat diinterpretasikan bahwa model regresi terbebas dari gejala heteroskedastisitas.

Uji linearitas adalah uji yang digunakan untuk mengetahui linear atau tidaknya hubungan antar masing-masing variabel penelitian.

Tabel 7. Hasil Pengujian Linearitas (Uji Lagrange Multiplier)

\begin{tabular}{|c|c|c|c|c|}
\hline \multicolumn{5}{|c|}{ Model Summary } \\
\hline Model & $\mathrm{R}$ & R Square & $\begin{array}{c}\text { Adjusted R } \\
\text { Square }\end{array}$ & $\begin{array}{c}\text { Std. Error of } \\
\text { the Estimate }\end{array}$ \\
\hline 1 & \multicolumn{5}{|c|}{$.027^{\mathrm{a}}$} & .001 & -.047 & 1.70635061 \\
\hline \multicolumn{5}{|c|}{ a. Predictors: (Constant), SIZE2, EPS2 } \\
\hline
\end{tabular}

Sumber: Output SPSS 21.0 data diolah

Diperoleh nilai $\mathrm{R}^{2}$ sebesar 0,001 dengan jumlah data observasi sebanyak 45 data. Maka, besarnya nilai $\mathrm{C}^{2}$ hitung:

$$
\begin{array}{ll}
\mathrm{C}^{2} \text { hitung } & =\mathrm{n} \times \mathrm{R}^{2} \\
\mathrm{C}^{2} \text { hitung } & =45 \times 0,001 \\
\mathrm{C}^{2} \text { hitung } & =0,045 \\
\mathrm{C}^{2} \text { tabel df } & =45-2=43 \text { adalah 59,30351 }
\end{array}
$$

Berdasarkan uji lagrange multiplier diperoleh nilai $\mathrm{C}^{2}$ hitung sebesar 0,045 dan nilai $\mathrm{C}^{2}$ tabel sebesar 59,30351. Dengan demikian nilai $C^{2}$ hitung $<$ nilai $C^{2}$ tabel $(0,045<$ $59,30351)$ maka dapat diinterpretasikan bahwa model regresi ini adalah linear.

Uji autokorelasi dimaksudkan untuk menguji model regresi linear terdapat hubungan atau korelasi antara kesalahan pengganggu periode $\mathrm{t}$ dengan kesalahan penganggu pada periode sebelumnya (t-1). Model regresi dihasilkanbaik bila Regresi bebas dari

\begin{tabular}{|c|c|c|c|c|c|}
\hline \multicolumn{6}{|c|}{ Model Summary ${ }^{b}$} \\
\hline Model & $\mathrm{R}$ & R Square & $\begin{array}{l}\text { Adjusted R } \\
\text { Square }\end{array}$ & $\begin{array}{l}\text { Std. Error of } \\
\text { the Estimate }\end{array}$ & $\begin{array}{l}\text { Durbin- } \\
\text { Watson }\end{array}$ \\
\hline 1 & $.353^{\mathrm{a}}$ & .124 & .082 & 1.49748 & 1.873 \\
\hline \multicolumn{6}{|c|}{ a. Predictors: (Constant), LAG_SIZE, LAG_EPS } \\
\hline \multicolumn{6}{|c|}{ b. Dependent Variable: LAG_PBV } \\
\hline
\end{tabular}
autokorelasi.

Tabel 8. Pengujian Autokorelasi Setelah Mengobati Gejala Autokorelasi (CochraneOrcutt)

Sumber: Output SPSS 21.0 data diolah

Setelah mengestimasi nilai $\rho$ dengan metode Cochrane-orcutt, diperoleh nilai DurbinWatson sebesar 1,873 yang lebih besar dari nilai dU yaitu 1,6148 dan kurang dari nilai 4dU yaitu 2,3852 $(1,6148<1,873<2,3852)$. Dapat diinterpretasikan model regresi ini tidak terdapat indikasi autokorelasi.

\section{Pengujian Hipotesis Pengaruh EPS Terhadap PBV}


Tabel 9. Hasil Pengujian Model Summary - Persamaan Regresi Model 1 - (EPS terhadap PBV)

\begin{tabular}{|c|r|r|r|r|}
\hline \multicolumn{5}{|c|}{ Model Summary } \\
\hline Model & R & R Square & $\begin{array}{c}\text { Adjusted R } \\
\text { Square }\end{array}$ & $\begin{array}{c}\text { Std. Error of } \\
\text { the Estimate }\end{array}$ \\
\hline 1 & $.320^{\mathrm{a}}$ & .103 & .081 & 1.49788 \\
\hline
\end{tabular}

a. Predictors: (Constant), LAG_EPS

Sumber: data olahan Output SPSS 21.0

Hasil pengujian Model Summary, diperoleh nilai $R$ Square sebesar 0,103 atau 10,3\%. Hasil ini menunjukkan bahwa variabel dependen (PBV) dapat dijelaskan oleh variabel independen (EPS) sebesar 10,3\%. Sedangkan sisanya yaitu 89,7\% dipengaruhi oleh variabel lain yang tidak dimasukkan dalam model penelitian ini. Adapun besarnya nilai e (error) yaitu:

$$
\begin{aligned}
& e=\sqrt{ }\left(1-R^{2}\right) \\
& e=\sqrt{ }(1-0,103) \\
& e=0,9471
\end{aligned}
$$

Dengan nilai e sebesar 0,9471 atau sebesar 94,71\%, maka diperoleh persamaan:

Tabel 10. Hasil Uji Parsial (Uji t) - Persamaan Regresi Model 1 - (EPS terhadap PBV)

\begin{tabular}{|l|l|r|r|r|r|r|}
\hline \multicolumn{2}{|c|}{ Coefficients $^{\mathbf{a}}$} \\
\hline \multirow{2}{*}{ Model } & \multicolumn{2}{|c|}{$\begin{array}{c}\text { Unstandardized } \\
\text { Coefficients }\end{array}$} & $\begin{array}{l}\text { Standardized } \\
\text { Coefficients }\end{array}$ & \multirow{2}{*}{ T } & \\
\cline { 3 - 6 } \multicolumn{2}{|c|}{} & B & Std. Error & Beta & & \\
\hline \multirow{2}{*}{1} & (Constant) & 1.150 & .256 & & 4.502 & .000 \\
\cline { 2 - 8 } & LAG_EPS & .002 & .001 & .320 & 2.191 & .034 \\
\hline
\end{tabular}

a. Dependent Variable: LAG_PBV

Sumber: data olahan Output SPSS 21.0

Hasil yang ditunjukkan oleh tabel 4.8 diperoleh persamaan regresi:

$\mathbf{Y}=\mathbf{a}+\mathbf{b}_{1} \mathbf{X}_{1}+\mathbf{e}$

\section{LAG_PBV = 1,150 + 0,002LAG_EPS + 0,9471}

Perhitungan dengan menggunakan alat analisis statistik SPSS 21.0 diperoleh hasil output uji parsial (uji t) tabel 4.7 dan 4.8 , diperoleh persamaan regresi model 1 LAG_PBV = $1,150+0,002 \mathrm{LAG}$ EPS $+0,9471$. Nilai koefisien-regresi variabel EPS sebesar 0,002, dan nilai $t_{\text {hitung }}$ sebesar 2,191 yang dibandingkan dengan nilai $t_{\text {tabel }}$ dengan taraf nyata $5 \%(\alpha=$ $0,05)$ dengan degree of freedom $(\mathrm{df})=45-4=41$ dihasilkan nilai $t_{\text {tabel }}$ sebesar 1,68288.

Gambar 1. Kurva Uji t (Hipotesis 1) 


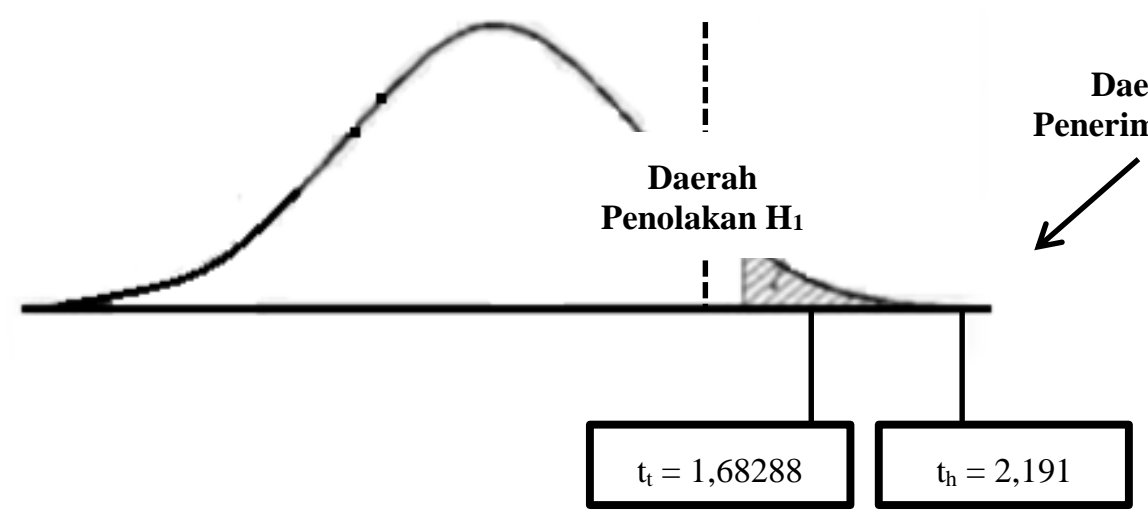

Hasil tersebut menunjukkan bahwa nilai $t_{\text {hitung }}$ lebih besar dari nilai $t_{\text {tabel }}$ atau $t_{\text {hitung }}>t_{\text {tabel }}$ $(2,191>1,68288)$ memiliki signifikansi sebesar 0,034 lebih kecil dari 0,05 $(0,034<$ $0,05)$, artinya variabel EPS memiliki pengaruh yang positif dan signifikan terhadap PBV. Dengan demikian maka $\mathrm{H}_{1}$ yang dirumuskan dalam hipotesis yaitu semakin meningkatnya Earning Per Share maka dapat meningkatkan Price Book Value diterima.

\section{Pengaruh Size Terhadap Price Book Value (PBV)}

Tabel 11. Hasil Pengujian Model Summary - Persamaan Regresi Model 2 - (SIZE terhadap PBV)

\begin{tabular}{|c|r|r|l|r|}
\hline \multicolumn{5}{|c|}{ Model Summary } \\
\hline Model & R & R Square & Adjusted R Square & Std. Error of the Estimate \\
\hline 1 & $.067^{\mathrm{a}}$ & .004 & -.019 & 1.57765 \\
\hline \multicolumn{7}{|c|}{ aredictors: (Constant), LAG_SIZE } \\
\hline
\end{tabular}

Sumber: data olahan Output SPSS 21.0

Hasil pengujian Model Summary, diperoleh nilai $R$ Square sebesar 0,004 atau 0,4\%. Hasil ini menunjukkan bahwa variabel dependen (PBV) diperoleh variabel independen (Size) sebesar $0,4 \%$. Sisanya yaitu $99,6 \%$ dipengaruhi oleh variabel yang tidak dimasukkan dalam model penelitian ini. Adapun besarnya nilai e (error) yaitu:

$$
\begin{aligned}
& e=\sqrt{ }\left(1-R^{2}\right) \\
& e=\sqrt{ }(1-0,004) \\
& e=0,9979
\end{aligned}
$$

Dengan nilai e sebesar 0,9980 atau sebesar 99,8\%

Tabel 12. Hasil Uji Parsial (Uji t) - Persamaan Regresi Model 2 - (SIZE terhadap PBV)

\begin{tabular}{|c|c|r|r|r|r|r|}
\hline \multicolumn{7}{|c|}{ Coefficients $^{\mathbf{a}}$} \\
\hline \multirow{2}{*}{ Model } & Unstandardized Coefficients & Standardized Coefficients & \multirow{2}{*}{ T } & \multirow{2}{*}{ Sig. } \\
\cline { 3 - 8 } \multicolumn{2}{|c|}{1} & B & Std. Error & Beta & & \\
\hline \multirow{2}{*}{1} & (Constant) & -.395 & 4.187 & & -.094 & .925 \\
\cline { 2 - 8 } & LAG_SIZE & .120 & .277 & .432 & .668 \\
\hline
\end{tabular}

a. Dependent Variable: LAG_PBV

Sumber: Output SPSS 21.0 data diolah

Hasil yang ditunjukkan oleh tabel 4.10 diperoleh persamaan regresi: 
$\mathbf{Y}=\mathbf{a}+\mathbf{b}_{2} \mathbf{X}_{2}+\mathbf{e}$

\section{LAG_PBV = -0,395 + 0,120LAG_SIZE + 0,9979}

Perhitungan dengan menggunakan alat analisis statistik SPSS 21.0 diperoleh hasil output uji parsial (uji t) tabel 4.9 dan 4.10, diperoleh persamaan regresi model 2 LAG_PBV = $0,395+0,120$ LAG_SIZE $+0,9979$. Nilai koefisien regresi variabel SIZE sebesar 0,120 bernilai positif, dan nilai $t_{\text {hitung }}$ sebesar 0,432 yang dibandingkan dengan nilai $t_{\text {tabel }}$ dengan taraf nyata $5 \%(\alpha=0,05)$ dengan degree of freedom $(\mathrm{df})=45-4=41$ menghasilkan nilai $\mathrm{t}_{\text {tabel }}$ sebesar 1,68288.

Gambar 2. Kurva Uji t (Hipotesis 2)

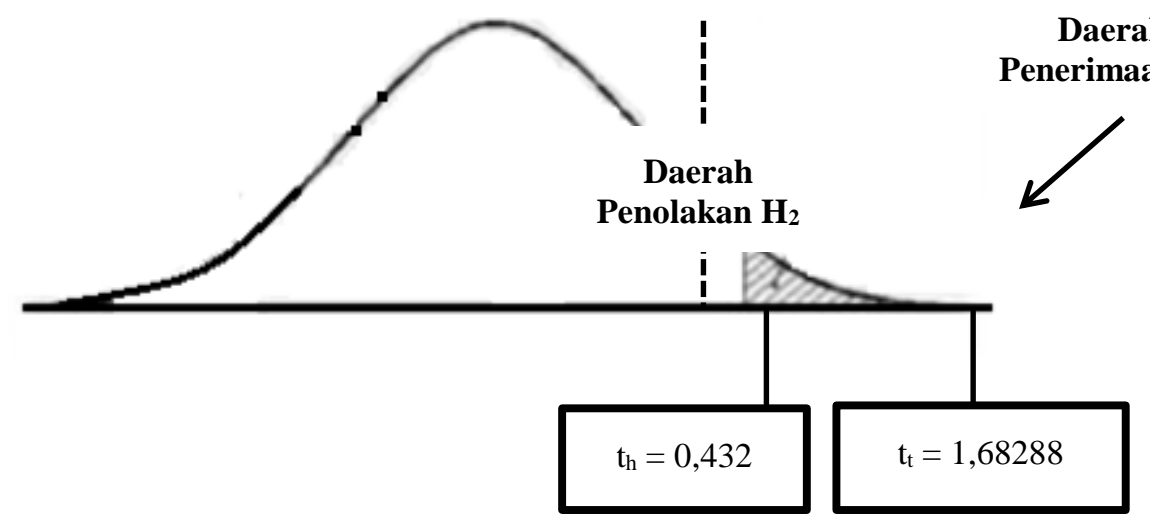

Hasil tersebut menunjukkan bahwa nilai $t_{\text {hitung }}$ lebih kecil dari nilai $t_{\text {tabel }}$ atau $t_{\text {hitung }}<\mathrm{t}_{\text {tabel }}$ $(0,432<1,68288)$ memiliki nilai signifikansi sebesar 0,668 lebih besar dari $0,05(0,668$ $>0,05)$, artinya Size tidak berpengaruh terhadap PBV. Dengan demikian maka $\mathrm{H}_{2}$ yang dirumuskan dalam hipotesis yaitu semakin besar ukuran perusahaan (size) maka dapat meningkatkan Price Book Value ditolak.

\section{Dividend Payout Ratio dalam Memoderasi Pengaruh EPS Terhadap PBV}

Tabel 13. Hasil Pengujian Model Summary - Persamaan Regresi Model 3 - (EPS terhadap PBV dengan DPR sebagai variabel moderasi)

\begin{tabular}{|c|c|c|c|c|}
\hline \multicolumn{5}{|c|}{ Model Summary } \\
\hline Model & $\mathrm{R}$ & R Square & $\begin{array}{c}\text { Adjusted R } \\
\text { Square }\end{array}$ & $\begin{array}{l}\text { Std. Error of } \\
\text { the Estimate }\end{array}$ \\
\hline 1 & $.378^{\mathrm{a}}$ & .143 & .101 & 1.48162 \\
\hline
\end{tabular}

Sumber: data olahan Output SPSS 21.0

Hasil pengujian Model Summary, diperoleh nilai $R$ Square sebesar 0,143 atau 14,3\%. Hasil ini menunjukkan bahwa variabel dependen (PBV) dapat dijelaskan oleh variabel independen (EPS) dan interaksi antara EPS dengan DPR sebesar 14,3\%. Sedangkan sisanya yaitu sebesar $85,7 \%$ dipengaruhi oleh variabel lain yang tidak dimasukkan dalam model penelitian ini. Adapun besarnya nilai e (error) yaitu:

$$
\begin{aligned}
& e=\sqrt{ }\left(1-R^{2}\right) \\
& e=\sqrt{ }(1-0,143)
\end{aligned}
$$


$\mathrm{e}=0,9257$

Dengan nilai e sebesar 0,9257 atau sebesar $92,57 \%$

Tabel 14. Hasil Pengujian Moderated Regression Analysis - Persamaan Regresi Model 3

- (EPS terhadap PBV dengan DPR sebagai variabel moderasi)

\begin{tabular}{|c|c|c|c|c|c|c|}
\hline \multicolumn{7}{|c|}{ Coefficients $^{\mathbf{a}}$} \\
\hline \multirow{2}{*}{\multicolumn{2}{|c|}{ Model }} & \multicolumn{2}{|c|}{$\begin{array}{l}\text { Unstandardized } \\
\text { Coefficients }\end{array}$} & \multirow{2}{*}{$\begin{array}{c}\begin{array}{c}\text { Standardized } \\
\text { Coefficients }\end{array} \\
\text { Beta }\end{array}$} & \multirow[t]{2}{*}{$\mathrm{t}$} & \multirow[t]{2}{*}{ Sig. } \\
\hline & & B & Std. Error & & & \\
\hline \multirow{3}{*}{1} & (Constant) & 1.074 & .259 & & 4.155 & .000 \\
\hline & LAG_EPS & .001 & .001 & .213 & 1.298 & .201 \\
\hline & Moderat1 & .003 & .000 & .228 & 1.788 & .042 \\
\hline
\end{tabular}

Sumber: Output SPSS 21.0 data diolah

Hasil yang ditunjukkan oleh tabel 4.12 diperoleh persamaan regresi:

$\mathbf{Y}=\mathbf{a}+\mathbf{b}_{1} \mathbf{X}_{1}+\mathbf{b}_{2} \mathbf{X}_{1} \mathbf{Z}+\mathbf{e}$

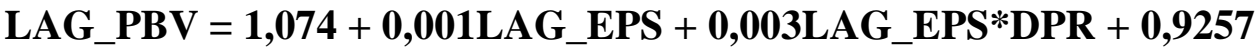

Perhitungan dengan menggunakan alat analisis statistik SPSS 21.0 diperoleh hasil output uji moderated regression analysis (MRA) tabel 4.11 dan tabel 4.12 dengan model persamaan 3 tentang persamaan regresi moderasi yaitu $\mathrm{Y}=\mathrm{a}+\mathrm{b}_{1} \mathrm{X}_{1}+\mathrm{b}_{2} \mathrm{X}_{1} \mathrm{Z}+\mathrm{e}$ yang

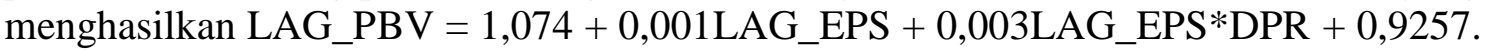
Terlihat bahwa koefisien regresi variabel interaksi LAG_EPS dengan DPR (Moderat1) bernilai positif artinya memiliki arah hubungan yang positif. Nilai thitung sebesar 1,788 dibandingkan dengan nilai tabel dengan taraf nyata $5 \%(\alpha=0,05)$ dengan degree of freedom $(\mathrm{df})=45-4=41$ menghasilkan nilai tabel sebesar 1,68288.

Gambar 3. Kurva Uji t (Hipotesis 3)

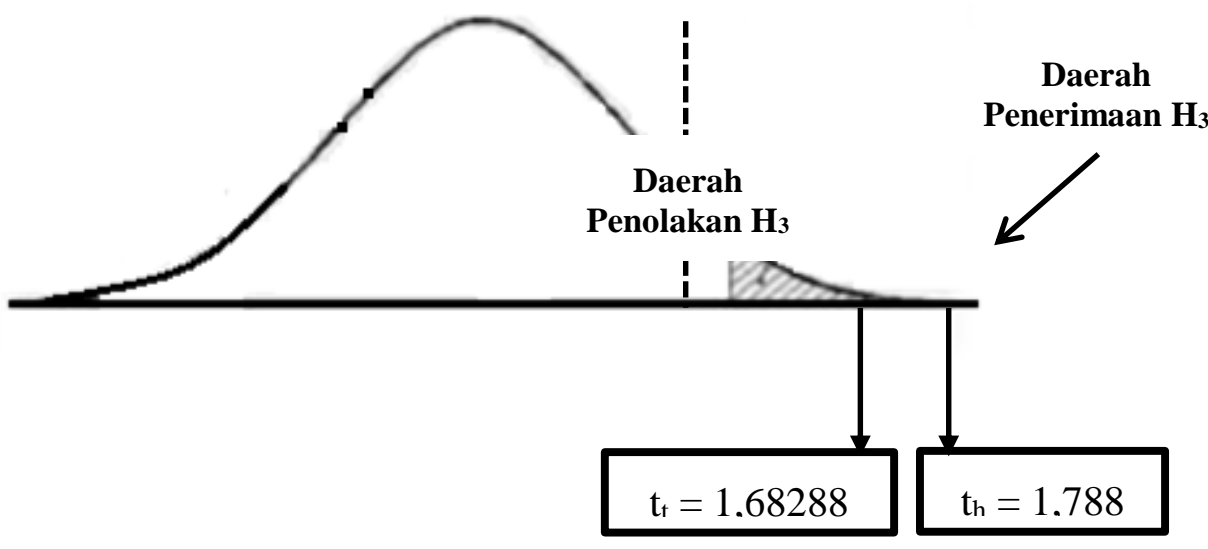

Hasil tersebut menunjukkan bahwa nilai $t_{\text {hitung }}$ lebih besar dari nilai $t_{\text {tabel }}$ atau $t_{\text {hitung }}>t_{\text {tabel }}$ $(1,788>1,68288)$ memiliki nilai signifikansi sebesar 0,042 lebih kecil dari 0,05 (0,042 $<0,05$ ), artinya variabel interaksi LAG_EPS dengan DPR (Moderat1) berpengaruh positif dan signifikan terhadap PBV. Dengan demikian maka $\mathrm{H}_{3}$ yang dirumuskan dalam 
hipotesis yaitu Dividend Payout Ratio (DPR) mampu memoderasi pengaruh Earning Per Share (EPS) terhadap Price Book Value (PBV) diterima.

\section{Dividend Payout Ratio dalam Memoderasi Pengaruh Size Terhadap PBV}

Tabel 15. Hasil Pengujian Model Summary - Persamaan Regresi Model 4 - (SIZE terhadap PBV dengan DPR sebagai variabel moderasi)

\begin{tabular}{|c|c|r|r|r|}
\hline \multicolumn{5}{|c|}{ Model Summary } \\
\hline Model & R & R Square & $\begin{array}{c}\text { Adjusted R } \\
\text { Square }\end{array}$ & $\begin{array}{c}\text { Std. Error of } \\
\text { the Estimate }\end{array}$ \\
\hline 1 & \multicolumn{6}{|c|}{$.070^{\mathrm{a}}$} & .005 & \multicolumn{2}{|c|}{-.044} & 1.59637 \\
\hline
\end{tabular}

Sumber: Output SPSS 21.0 data diolah

Hasil pengujian Model Summary, diperoleh nilai $R$ Square sebesar 0,005 atau 0,5\%. Hasil ini menunjukkan bahwa variabel dependen (PBV) dapat dijelaskan oleh variabel independen (Size) dan interaksi antara Size dengan DPR sebesar 0,5\%. Sedangkan sisanya yaitu sebesar 99,5\% dipengaruhi oleh variabel lain yang tidak dimasukkan dalam model penelitian ini. Adapun besarnya nilai e (error) yaitu:

$$
\begin{aligned}
& e=\sqrt{ }\left(1-R^{2}\right) \\
& e=\sqrt{ }(1-0,005) \\
& e=0,9974
\end{aligned}
$$

Dengan nilai e sebesar 0,9974 atau sebesar 99,74\%

\begin{tabular}{|c|c|c|c|c|c|c|}
\hline \multicolumn{7}{|c|}{ Coefficients $^{\mathbf{a}}$} \\
\hline \multirow{2}{*}{\multicolumn{2}{|c|}{ Model }} & \multicolumn{2}{|c|}{$\begin{array}{l}\text { Unstandardized } \\
\text { Coefficients }\end{array}$} & \multirow{2}{*}{$\begin{array}{c}\text { Standardized } \\
\text { Coefficients } \\
\text { Beta }\end{array}$} & \multirow[t]{2}{*}{$\mathrm{t}$} & \multirow[t]{2}{*}{ Sig. } \\
\hline & & $\mathrm{B}$ & Std. Error & & & \\
\hline \multirow{3}{*}{1} & (Constant) & -.394 & 4.237 & & -.093 & .926 \\
\hline & LAG_SIZE & .120 & 280 & .067 & .430 & .670 \\
\hline & Moderat2 & -.001 & .000 & -.023 & -.145 & .885 \\
\hline
\end{tabular}

Tabel 16. Hasil Pengujian Moderated Regression Analysis - Persamaan Regresi Model 4 - (SIZE terhadap PBV dengan DPR sebagai variabel moderasi)

Sumber: Output SPSS 21.0 data diolah

Hasil pada tabel 4.14 diperoleh persamaan regresi:

$\mathbf{Y}=\mathbf{a}+\mathbf{b}_{1} \mathbf{X}_{2}+\mathbf{b}_{2} \mathbf{X}_{2} \mathbf{Z}+\mathbf{e}$

$$
\text { LAG_PBV = -0,394 + 0,120LAG_SIZE - 0,001LAG_SIZE*DPR + 0,9974 }
$$

Perhitungan dengan menggunakan alat analisis statistik SPSS 21.0 diperoleh hasil output uji moderated regression analysis (MRA) tabel 4.13 dan tabel 4.14 dengan model persamaan 4 tentang persamaan regresi moderasi yaitu $Y=a+b_{1} X_{2}+b_{2} X_{2} Z+e$ yang

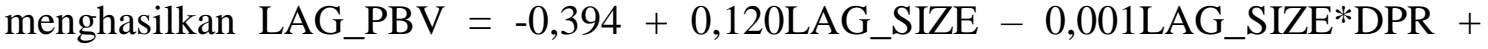
0,9974. Terlihat bahwa koefisien regresi variabel interaksi LAG_SIZE dengan DPR (Moderat2) bernilai negatif artinya memiliki arah hubungan yang negatif. Nilai $-t_{\text {hitung }}$ 
sebesar -0,145 dibandingkan dengan nilai tabel dengan taraf nyata $5 \%(\alpha=0,05)$ dengan degree of freedom $(\mathrm{df})=45-4=41$ menghasilkan nilai $-\mathrm{t}_{\text {tabel }}$ sebesar $-1,68288$.

Gambar 4. Kurva Uji t (Hipotesis 4)

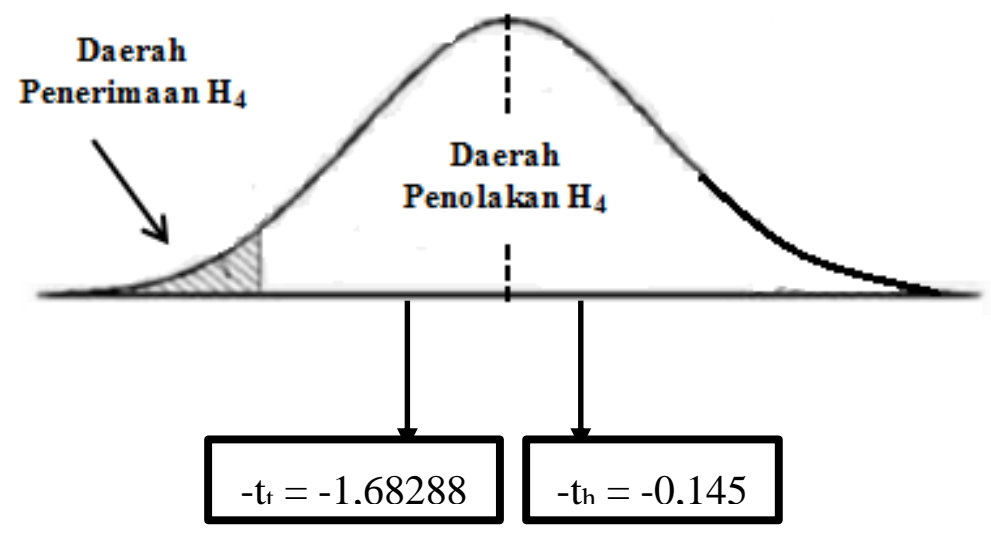

Hasil tersebut menunjukkan bahwa nilai - $t_{\text {hitung }}$ lebih besar dari nilai $-t_{\text {tabel }}$ atau $-t_{\text {hitung }}>$ $t_{\text {tabel }}(-0,145>-1,68288)$ serta memiliki nilai signifikansi sebesar 0,885 lebih besar dari $0,05(0,885>0,05)$ tidak signifikan, artinya variabel interaksi LAG_SIZE dengan DPR (Moderat2) tidak mampu memoderasi pengaruh Size terhadap PBV. Dengan demikian maka $\mathrm{H}_{4}$ yang dirumuskan dalam hipotesis yaitu Dividend Payout Ratio (DPR) mampu memoderasi pengaruh Size Firm terhadap Price Book Value ditolak.

\section{Pengaruh Earning Per Share (EPS) Terhadap Price Book Value (PBV)}

Berdasarkan hasil pengujian hipotesis uji parisal (uji t) diperoleh persamaan LAG_PBV $=1,150+0,002 \mathrm{LAG} \_$EPS $+0,9471$. Dilihat dari nilai koefisien regresi variabel EPS sebesar 0,002 bernilai positif, serta dilihat dari nilai thitung sebesar 2,191 yang dibandingkan dengan nilai $t_{\text {tabel }}$ sebesar 1,68288 ( $\left.t_{\text {hitung }}>t_{\text {tabel }}\right)$ atau $(2,191>1,68288)$ serta memiliki nilai signifikansi sebesar 0,034 lebih kecil dari $0,05(0,034<0,05)$. Maka dapat diinterpretasikan bahwa Earning Per Share (EPS) memiliki pengaruh yang positif signifikan terhadap PBV yang artinya semakin meningkatnya EPS maka dapat meningkatkan PBV.

Penelitian ini sejalan dengan signaling theory, bahwa tingginya tingkat laba (profit) dapat menjadi sinyal positif bagi investor dan dapat membuat harga saham perusahaan mengalami peningkatan. Harga saham yang tinggi akan mencerminkan nilai perusahaan yang baik.

Hasil penelitian ini sesuai dengan hipotesis yang diajukan peneliti dan sejalan dengan penelitian Amalia Dewi Rahmawati, Topowijono dan Sulasmiyati (2015) yang hasilnya menunjukkan profitabilitas berpengaruh positif dan signifikan terhadap nilai perusahaan.

\section{Pengaruh Size Terhadap Price Book Value (PBV)}

Hasil pengujian hipotesis uji parisal (uji t) diperoleh persamaan LAG_PBV $=-0,395$ $+0,120$ LAG_SIZE $+0,9979$. Dilihat dari nilai koefisien regresi variabel Size sebesar 0,120 serta dilihat dari nilai $t_{\text {hitung }}$ sebesar 0,432 yang dibandingkan dengan nilai $t_{\text {tabel }}$ 
sebesar $1,68288\left(\mathrm{t}_{\text {hitung }}<\mathrm{t}_{\text {tabel }}\right)$ atau $(0,432<1,68288)$ serta memiliki nilai signifikansi sebesar 0,668 lebih besar dari 0,05 atau $(0,668>0,05)$. Dapat diinterpretasikan bahwa Size tidak berpengaruh terhadap PBV. Artinya bahwa semakin besar ukuran perusahaan (size) tidak dapat meningkatkan nilai perusahaan.

Hal ini menunjukkan bahwa besar atau kecilnya suatu perusahaan di sektor properti, real estate serta konstruksi bangunan pada periode 2013-2017 tidak akan mempengaruhi nilai perusahaan. Besar kecilnya ukuran perusahaan tidak terlalu menjadi perhatian investor. Apabila ingin menilai suatu perusahaan, sebagian investor tidak akan melihat dari segi ukuran perusahaan melainkan akan lebih meninjau dari berbagai aspek seperti melihat kinerja perusahaan melalui laporan keuangan perusahaan, nama baik perusahaan, atau kebijakan dalam pembagian dividen.

Hasil penelitian ini tidak sesuai dengan hipotesis yang diajukan peneliti dan tidak sejalan dengan penelitian terdahulu yang menjadi pendukung yakni penelitian yang dilakukan oleh Putra dan Lestari (2016) yang hasilnya menunjukkan bahwa ukuran perusahaan berpengaruh positif signifikan terhadap nilai perusahaan. Namun hasil penelitian ini sejalan dengan penelitian bersama Suwardika dan Mustanda (2017) yang menyatakan ukuran perusahaan tidak memperngaruhi nilai perusahaan.

\section{Pengaruh Dividend Payout Ratio (DPR) dalam Memoderasi EPS Terhadap PBV}

Hasil pengujian Moderated Regression Analysis (Uji MRA) diperoleh persamaan LAG_PBV $=1,074+0,001 \mathrm{LAG} \_$EPS $+0,003 \mathrm{LAG} \_$EPS $*$ DPR $+0,9257$. Dilihat dari nilai koefisien regresi variabel interaksi EPS*DPR sebesar 0,003 bernilai positif, selanjutnya dilihat dari nilai thitung sebesar 1,788 yang dibandingkan dengan nilai $t_{\text {tabel }}$ sebesar 1,68288 ( $\left.t_{\text {hitung }}>t_{\text {tabel }}\right)$ atau $(1,788>1,68288)$ serta memiliki nilai signifikansi sebesar 0,042 lebih kecil dari 0,05 $(0,042<0,05)$. Maka dapat diinterpretasikan bahwa DPR mampu memoderasi EPS terhadap PBV. Hal ini menjadi indikasi bahwa kebijakan perusahaan dalam membagikan dividen dapat meningkatkan nilai perusahaan disaat laba yang diperoleh tinggi. Dengan dibagikannya dividen kepada investor maka investor akan menilai jika perusahaan tersebut mempunyai nilai perusahaan yang baik dan mempunyai prospek yang baik untuk masa mendatang. Begitu juga sebaliknya, kebijakan dividen dapat menurunkan nilai perusahaan jika laba yang diperoleh perusahaan tersebut rendah. Hal ini sesuai dengan signaling theory yang menyatakan bahwa pembagian dividen dapat menjadi sinyal yang baik bagi investor karena investor lebih menyukai pembayaran dividen.

Hasil penelitian ini sesuai dengan hipotesis yang diajukan peneliti dan sejalan dengan penelitian yang dilakukan oleh Mery (2017), Ayu dan Emrinaldi (2017) yang menyatakan bahwa kebijakan dividen mampu memoderasi pengaruh profitabilitas terhadap nilai perusahaan.

\section{Pengaruh Dividend Payout Ratio (DPR) dalam Memoderasi Pengaruh Size Terhadap Price Book Value (PBV)}

Hasil pengujian Moderated Regression Analysis (Uji MRA) diperoleh persamaan LAG_PBV $=-0,394+0,120 \mathrm{LAG} \_S I Z E-0,001 \mathrm{LAG} \_S I Z E^{*} \mathrm{DPR}+0,9974$. Dilihat dari nilai koefisien regresi variabel interaksi SIZE*DPR sebesar $-0,001$ bernilai negatif, selanjutnya dilihat dari nilai - $t_{\text {hitung }}$ sebesar $-0,145$ yang dibandingkan dengan nilai $t_{\text {tabel }}$ sebesar $-1,68288\left(-t_{\text {hitung }}>-t_{\text {tabel }}\right)$ atau $(-0,145>-1,68288)$ serta memiliki nilai




signifikansi sebesar 0,885 lebih besar dari $0,05(0,885>0,05)$. Maka dapat diinterpretasikan bahwa DPR tidak mampu memoderasi pengaruh Size terhadap PBV. Hal ini menjadi indikasi bahwa kebijakan perusahaan dalam membagikan dividen tidak akan mempengaruhi nilai perusahaan baik untuk perusahaan dengan skala besar maupun kecil.

Hasil penelitian ini tidak sesuai dengan hipotesis yang diajukan peneliti dan tidak sejalan dengan penelitian yang dilakukan oleh Kalsum, dkk (2017) yang hasilnya menunjukkan kebijakan dividen mampu memoderasi size terhadap nilai perusahaan. Namun penelitian ini sejalan dengan hasil yang dilakukan oleh Siti Khuswatun Khasanah dan Titik Aryati (2019) yang menyatakan bahwa kebijakan dividen tidak mampu memperkuat hubungan antara ukuran perusahaan dengan nilai perusahaan.

\section{Kesimpulan}

Berdasarkan hasil perhitungan dan pembahasan diatas, maka diperoleh kesimpulan: (a) Profitabilitas berpengaruh positif dan signifikan terhadap nilai perusahaan; (b) Ukuran perusahaan (size) tidak berpengaruh terhadap nilai perusahaan; (c) Kebijakan dividen mampu memoderasi profitabilitas terhadap nilai perusahaan; (d) Kebijakan dividen tidak mampu memoderasi size terhadap nilai perusahaan.

Bagi peneliti selanjutnya: (a) Sebaiknya periode untuk penelitian selanjutnya dapat diperpanjang, tidak terbatas hanya pada kondisi perusahaan selama lima tahun terakhir. Hal ini guna mendapatkan hasil yang signifikan mengenai kebijakan dividen dalam memoderasi Size Firm terhadap PBV; (b) Penentuan populasi dan sampel sebaiknya diperluas dan tidak hanya terbatas pada perusahaan sektor properti, real estate dan konstruksi bangunan saja, hal ini agar dapat lebih mewakili kondisi perusahaan yang terdaftar di Bursa Efek Indonesia (BEI); (c) Menambah faktor-faktor lain yang mempengaruhi nilai perusahaan. Selain itu, dapat pula mengganti variabel moderasi selain kebijakan dividen seperti variabel likuiditas atau kebijakan hutang yang dianggap mampu memoderasi pengaruh ukuran perusahaan terhadap nilai perusahaan. Perusahaan diharapkan dapat lebih meningkatkan kinerja keuangannya seperti penggunaan modal untuk meningkatkan laba dan pemanfaatan asset yang dimiliki serta kebijakan dalam pembagian dividen kepada para investor guna mensejahterakan pemegang saham dan untuk membuat citra yang baik bagi perusahaan. Hal ini karena kinerja keuangan dianggap sebagai salah satu hal penting bagi investor dalam menilai prospek perusahaan baik dimasa sekarang maupun maupun dimasa yang akan datang. Dengan meningkatnya kinerja keuangan perusahaan, maka akan menarik investor untuk berinvestasi sehingga akan meningkatkan nilai perusahaan.

\section{Referensi}

Armereo, C. (2015). Analisis Faktor-Faktor yang Mempengaruhi Profitabilitas Bank Syariah yang Terdaftar di Bursa Efek Indonesia Indonesia. Jurnal Ilmiah Ekonomi Global Masa Kini, 6(2), 48-56.

Ayu, R.P., \& Emrinaldi. (2017). Pengaruh kinerja keuangan terhadap nilai perusahaan dengan kebijakan dividen sebagai faktor pemoderasi. Jurnal Tepak Manajemen Bisnis, IX(1). 
Halin, H. (2016). Pengaruh Rasio Lancar Dan Rasio Hutang Terhadap Profitabilitas Pada Industri Telekomunikasi Yang Listing Di Bursa Efek Indonesia. Jurnal Ilmiah Ekonomi Global Masa Kini, 7(1), 49-54.

Purnamasari, E. D. (2017). Analisis Pengaruh Laverage terhadap Profitabilitas Perusahaan yang Termasuk LQ45 Periode Agustus 2015-Januari 2016 di Bursa Efek Indonesia. Jurnal Ilmiah Ekonomi Global Masa Kini, 8(1), 41-45.

Kasmir. (2014). Analisis Laporan Keuangan. Jakarta: PT Raja Grafindo Persada.

Kusumayanti, N.K.R., \& Astika, I.B.P. (2016). Corporate social responsibility sebagai pemediasi pengaruh ukuran perusahaan, profitabilitas dan leverage pada nilai perusahaan. E-Jurnal Akuntansi Universitas Udayana, 15(1), 549-583.

Mery, K.N. (2017). Pengaruh likuiditas, leverage, dan profitabilitas terhadap nilai perusahaan dengan kebijakan dividen sebagai variabel moderasi. JOM Fekon, 4(1).

Novari, P.M., \& Lestari, P.V. (2016). Pengaruh ukuran perusahaan, leverage, dan profitabilitas terhadap nilai perusahaan pada sektor properti dan real estate. E-Jurnal Manajemen Unud, 5(9), 5671-5694.

Putra, A.N.D.A., \& Lestari, P.V. (2016). Pengaruh kebijakan dividen, likuiditas, profitabilitas dan ukuran perusahaan terhadap nilai perusahaan. E-Jurnal Manajemen Unud, 5(7), 4044-4070.

Rahmawati, A.D., Topowijono., \& Sulasmiyati, S. (2015). Pengaruh ukuran perusahaan, profitabilitas, struktur modal, dan keputusan investasi terhadap nilai perusahaan. Jurnal Administrasi Bisnis (JAB), 23(2).

Sayadi, M. H. (2019). Evaluasi Kinerja Keuangan Sebelum dan Sesudah Akuisisi Menggunakan Profitabilitas. Jurnal Ilmiah Ekonomi Global Masa Kini, 10(1), 8-12.

Suwardika, I.N.A., \& Mustanda, I.K. (2017). Pengaruh leverage, ukuran perusahaan, pertumbuhan perusahaan, dan profitabilitas terhadap nilai perusahaan pada perusahaan properti. E-Jurnal Manajemen Unud, 6(3).

\section{Copyrights}

Copyright for this article is retained by the author(s), with first publication rights granted to the journal.

This is an open-access article distributed under the terms and conditions of the Creative Commons Attribution license (http://creativecommons.org/licenses/by/4.0/). 